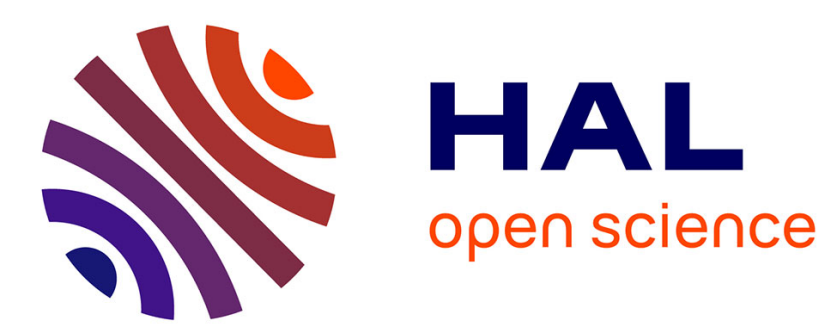

\title{
Freezing stallion semen in INRA96®-based extender improves fertility rates in comparison with INRA82
}

Elodie Pillet, Florence Batellier, Guy Duchamp, Vincent V. Furstoss, Yves Le Vern, Dominique Kerboeuf, Marianne Vidament, Michèle Magistrini

\section{- To cite this version:}

Elodie Pillet, Florence Batellier, Guy Duchamp, Vincent V. Furstoss, Yves Le Vern, et al.. Freezing stallion semen in INRA96®-based extender improves fertility rates in comparison with INRA82. Dairy Science \& Technology, 2008, 88 (2), pp.257-265. 10.1051/dst:2008002 . hal-02657861

\section{HAL Id: hal-02657861 https://hal.inrae.fr/hal-02657861}

Submitted on 30 May 2020

HAL is a multi-disciplinary open access archive for the deposit and dissemination of scientific research documents, whether they are published or not. The documents may come from teaching and research institutions in France or abroad, or from public or private research centers.
L'archive ouverte pluridisciplinaire HAL, est destinée au dépôt et à la diffusion de documents scientifiques de niveau recherche, publiés ou non, émanant des établissements d'enseignement et de recherche français ou étrangers, des laboratoires publics ou privés.

$$
\text { Copyright }
$$




\title{
Freezing stallion semen in INRA96 ${ }^{\circledR}$-based extender improves fertility rates in comparison with INRA82
}

\author{
Elodie PILleT $^{1,2}$, Florence BATELliER ${ }^{1}$, Guy DUCHAMP ${ }^{3}$, Vincent Furstoss ${ }^{4}$, \\ Yves LE VERN ${ }^{5}$, Dominique KERBOEUF ${ }^{5}$, Marianne VIDAMENT ${ }^{1}$, \\ Michèle MAGISTRINI ${ }^{1 *}$ \\ ${ }^{1}$ INRA, UMR85 Physiologie de la Reproduction et des Comportements, 37380 Nouzilly, France; \\ CNRS, 37380 Nouzilly, France; Université de Tours, 37041 Tours, France; \\ Haras Nationaux, 37380 Nouzilly, France \\ 2 IMV-Technologies, 10 rue Clemenceau, 61302 L'Aigle, France \\ ${ }^{3}$ INRA, UE992 Unité pluri-espèces d'expérimentation animale en physiologie de la reproduction \\ et des comportements, 37380 Nouzilly, France \\ ${ }^{4}$ INRA, UE88 Insémination caprine et porcine, 86480 Rouillé, France \\ ${ }^{5}$ INRA, Service de Cytométrie en Flux, 37380 Nouzilly, France
}

Received 20 November 2007 - Accepted 16 January 2008

\begin{abstract}
The chemical composition of freezing extenders plays a major role in sperm cell survival during cryopreservation. In this study we compared two extenders for freezing stallion semen: INRA82 extender (as a control) versus INRA96 ${ }^{\circledR}$ extender, both supplemented with egg yolk and glycerol. INRA82 contains milk, whereas INRA96 ${ }^{\circledR}$ is a chemically-defined extender developed for fresh semen storage at $4{ }^{\circ} \mathrm{C}$ or $15{ }^{\circ} \mathrm{C}$. Semen from 3 stallions (7 ejaculates per stallion) was frozen in both extenders. In vitro analyses of post-thaw motility of sperm cells (computer-assisted analysis) and of membrane integrity (flow cytometry analysis) were performed. Then a fertility trial was conducted. Inseminations were conducted in a total of 84 mare cycles. INRA96 ${ }^{\circledR}$ extender supplemented with egg yolk and glycerol significantly improved per-cycle pregnancy rates compared with INRA82 $(71 \%$ versus $40 \%, p<0.01)$. In agreement with these fertility results, membrane integrity was better preserved in INRA $96^{\circledR}$ than in INRA82. In contrast, motility parameters were significantly higher in INRA82 than in INRA96 ${ }^{\circledR}$. Further research is needed to understand how INRA96 ${ }^{\circledR}$ components protect sperm cells during the cryopreservation process and highly increase their fertility potential compared with INRA82 components.
\end{abstract}

cryopreservation / semen / INRA96 ${ }^{\circledR}$ extender / fertility / stallion

摘要 - 利用 INRA96 ${ }^{\circledR}$ 混合剂提高冻藏马精液受精率的研究。冷冻剂的化学成分对提高 低温保藏精子细胞的存活率具有重要作用。本文比较了两种精子冷冻剂 INRA82 (对照 组) 和 INRA96 ${ }^{\circledR}$ 对马精液的冷冻保护作用, 两种保护剂中都添加了蛋黄和甘油, INRA82 中主要含有牛奶, 而 INRA $96^{\circledR}$ 是一种化学混合物, 该保护剂最初是用于新采集的马精液 在 $4{ }^{\circ} \mathrm{C}$ 或 $15^{\circ} \mathrm{C}$ 下陉藏的保护剂。将采集的 $3 匹$ 种马 (收集每匹马7次的精液) 的精液放在 两种冷冻剂里进行冷冻试验, 体外分析了解冻后精子细胞的运动能力 (计算机辅助分析)

*Corresponding author (通讯作者): michele.magistrini@tours.inra.fr 
和细胞膜的完整性 (流式细胞仪分析), 并进行了授精能力试验。共在 84 个排卵期内进行授 精试验。与 INRA82 相比, 添加了蛋黄和甘油的 INRA96 ${ }^{\circledR}$ 能明显提高了每个排卵期的受孕 率 $\left(71 \%\right.$ INRA96 ${ }^{\circledR}, 40 \%$ INRA $\left.82, p<0.01\right)$, 而且细胞膜的完整性优于前者; 但是在 INRA82 中冷冻精子运动参数明显高于 INRA96 ${ }^{\circledR}$ 。至于 INRA96 ${ }^{\circledR}$ 在低温咜存过程中的保护机理以 及如何提高授精潜力, 还有待进一步研究。

\section{低温保藏 / 精液 / INRA96 ${ }^{\circledR}$ 冷冻剂 / 授精能力 / 种马}

Résumé - La congélation de semence d'étalon dans un milieu à base d'INRA96 ${ }^{\circledR}$ améliore le taux de fertilité en comparaison avec le milieu INRA82. La composition chimique des milieux de congélation joue un rôle majeur dans le maintien de l'intégrité des spermatozoïdes au cours de la cryoconservation. Dans cette étude, nous avons comparé deux milieux pour congeler la semence d'étalon : le milieu INRA82 (utilisé comme milieu contrôle) versus le milieu INRA96 ${ }^{\circledR}$, tous deux supplémentés de jaune d'œuf et de glycérol. L'INRA82 contient du lait alors que l'INRA96 ${ }^{\circledR}$ est un milieu chimiquement défini, mis au point pour la conservation de la semence à $4{ }^{\circ} \mathrm{C}$ ou $15^{\circ} \mathrm{C}$. La semence de 3 étalons (7 éjaculats par étalon) a été congelée dans ces 2 milieux. Des analyses in vitro de la mobilité des spermatozoïdes (analyse automatisée assistée par ordinateur), ainsi que de l'intégrité membranaire (analyse en cytométrie en flux) ont été réalisées. Une expérience de fertilité a ensuite été conduite. Un total de 84 cycles de juments a été inséminé. Les résultats ont montré que le milieu INRA96 ${ }^{\circledR}$ supplémenté de jaune d'œuf et de glycérol améliore significativement les taux de fertilité par cycle comparé au milieu INRA82 (71\% versus $40 \%, p<0.01)$. En accord avec ces résultats de fertilité, l'intégrité membranaire a été mieux préservée dans l'INRA96 ${ }^{\circledR}$. Par contre, la mobilité des spermatozoïdes a été significativement plus élevée dans l'INRA82 que dans l'INRA96 ${ }^{\circledR}$. Des recherches complémentaires sont conduites pour comprendre comment les composants du milieu INRA96 ${ }^{\circledR}$ protègent les spermatozoïdes au cours du processus de cryoconservation et augmentent le potentiel de fertilité comparés aux composants du milieu INRA82.

\section{cryoconservation / semence / milieu INRA96 ${ }^{\circledR}$ / fertilité / étalon}

\section{INTRODUCTION}

Cryopreservation is well adapted to semen storage and to semen exchanges between laboratories and countries but this technology is detrimental to the viability and functional integrity of sperm cells. As freeze-thaw procedures lead to a decrease in the percentage of intact sperm cells, fertility with frozen semen is impaired [19]. In field conditions in France, per-cycle pregnancy rates in the stallion are only 45$48 \%$ after inseminations performed with frozen semen compared with 57-59\% with fresh semen [18].

The chemical composition of freezing extenders plays a major role in the survival of sperm cells during cryopreservation. Interestingly, in the stallion, the first successful pregnancy with frozen semen was obtained with epididymal sperm cells cryopreserved in a heated whole-milk extender containing 10\% glycerol [1]. Most extenders used to freeze stallion semen are based on milk and/or egg yolk [16] (notably INRA82 extender [12,13]). Milk and egg yolk contain sugars and proteins and are sources of energy and protection against cold shock for sperm cells. However, both are also biological substances which may differ between batches. In addition, milk and egg yolk are extremely complex animal products which may contain components with beneficial and detrimental effects on sperm cells. In milk, $\beta$-lactoglobulin and native phosphocaseinate appear to be two major components with a beneficial effect on sperm cells. Thus, Batellier et al. in 1997 [2] developed an extender containing native phosphocaseinate instead of milk: INRA96 ${ }^{\circledR}$ extender. INRA96 ${ }^{\circledR}$ is indeed a chemically-defined extender which maintains the fertility potential of stallion spermatozoa during chilled storage at $4{ }^{\circ} \mathrm{C}$ or $15{ }^{\circ} \mathrm{C}$ for 24 to $72 \mathrm{~h} \mathrm{[5].}$ 
The aim of the present study was to assess the effectiveness of INRA96 ${ }^{\circledR}$ extender supplemented with egg yolk and glycerol for freezing stallion semen. For this purpose, INRA96 ${ }^{\circledR}$ was compared with INRA82 (as a control) for freezing stallion semen. After in vitro analyses of post-thaw motility and membrane integrity of sperm cells, a fertility trial was conducted.

\section{MATERIALS AND METHODS}

\subsection{Extenders}

Two semen extenders were compared: INRA82 supplemented with chicken egg yolk and glycerol used as the control extender, and INRA96 ${ }^{\circledR}$ supplemented with chicken egg yolk and glycerol. The INRA82 extender consisted of $0.5 \mathrm{~L}$ glucose-saline solution $\left(25 \mathrm{~g} \cdot \mathrm{L}^{-1} \mathrm{glu}-\right.$ cose, $1.5 \mathrm{~g} \cdot \mathrm{L}^{-1}$ lactose, $1.5 \mathrm{~g} \cdot \mathrm{L}^{-1}$ raffinose, $0.25 \mathrm{~g} \cdot \mathrm{L}^{-1}$ sodium citrate dehydrate, $0.41 \mathrm{~g} \cdot \mathrm{L}^{-1}$ potassium citrate and $4.76 \mathrm{~g} \cdot \mathrm{L}^{-1}$ Hepes buffer) and $0.5 \mathrm{~L}$ ultra-heat-treated (UHT) skim milk, with $\mathrm{pH}$ adjusted to 6.8. INRA82 also contained 50000 UI penicillin and $50 \mathrm{mg}$ gentamicin per liter. All chemicals were purchased from SigmaAldrich Chimie (Saint-Quentin Fallavier, France). The INRA96 ${ }^{\circledR}$ extender consisted of a HGLL solution containing Hank's salts, glucose and lactose, buffered by Hepes (4.76 g. $\mathrm{L}^{-1}$ Hepes buffer) and supplemented with a purified fraction of caseins (native phosphocaseinate) [2]. The $\mathrm{pH}$ is adjusted to 7.1. INRA96 ${ }^{\circledR}$ also contained $50000 \mathrm{UI}$ penicillin, $50 \mathrm{mg}$ gentamicin, and $0.25 \mathrm{mg}$ amphotericine B per liter. INRA96 ${ }^{\circledR}$ is distributed in a readyto-use liquid form by IMV-Technologies (L'Aigle, France). This extender is sterilized by the manufacturer and stored at $4{ }^{\circ} \mathrm{C}$ before use. Thus, in the freezing procedure the first dilution was performed in INRA82 or in INRA96 ${ }^{\circledR}$. The second dilution and freezing were then performed in INRA82 supplemented with $2 \%$ of centrifuged egg yolk (own preparation) and $2.5 \%$ of glycerol (INRA82 $+\mathrm{EY}+\mathrm{G}$ ) or in INRA96 ${ }^{\circledR}$ supplemented with $2 \%$ of centrifuged egg yolk and $2.5 \%$ of glycerol $\left(\right.$ INRA96 $\left.{ }^{\circledR}+E Y+G\right)$. Only one batch of these extenders was prepared and stored in $50 \mathrm{~mL}$ aliquots at $-20{ }^{\circ} \mathrm{C}$ until use.

\subsection{Stallions and semen collection}

The study included three mature Welsh stallions of proven fertility. The stallions were housed at INRA in Nouzilly, France. Semen was collected from these stallions in May on a regular basis (three times a week) by using a closed artificial vagina. Seven ejaculates per stallion were processed. The three stallions' semen was collected on the same day ( $n=7$ days of collection). After collection, raw semen was filtered through gauze to exclude the gel fraction of the ejaculate and immediately processed.

\subsection{Semen freezing and thawing}

Filtered semen of each ejaculate was divided into two aliquots which were diluted either in INRA 82 or in INRA $96^{\circledR}$. The minimum dilution ratio was 1:3 (1 part of semen plus 3 parts of extender). Upon semen collection, ejaculates were diluted and cooled $\left(22{ }^{\circ} \mathrm{C}\right.$ for $\left.10 \mathrm{~min}\right)$ and then centrifuged $(600 \times g$ for $10 \mathrm{~min})$. After centrifugation the pellet was resuspended either in INRA82 $+\mathrm{EY}+\mathrm{G}$ or in INRA96 ${ }^{\circledR}+\mathrm{EY}+\mathrm{G}$ to obtain $100 \times 10^{6}$ sperm cells. $\mathrm{mL}^{-1}$. Each tube of diluted semen was cooled to $4{ }^{\circ} \mathrm{C}$ over $75 \mathrm{~min}$. The cooled semen was loaded into $0.5 \mathrm{~mL}$ polyvinyl chloride straws (IMV-Technologies, L'Aigle, France) that were then sealed with polyvinyl alcohol sealing powder. Freezing was performed with a programable freezer (nitrogen freezer, automatic Mini-Digitcool, 
IMV-Technologies, L'Aigle, France) $\left(-60{ }^{\circ} \mathrm{C} \cdot \mathrm{min}^{-1}\right.$ until $\left.-140^{\circ} \mathrm{C}\right)$. The straws were kept in liquid nitrogen and then thawed in a water bath $\left(37^{\circ} \mathrm{C}\right.$ for $\left.30 \mathrm{~s}\right)$ immediately before analyses or artificial inseminations.

\subsection{Assessment of motility}

Semen from each of the 7 ejaculates was thawed and diluted in INRA82 or INRA96 ${ }^{\circledR}$ until a concentration of $20 \times$ $10^{6}$ sperm cells $\cdot \mathrm{mL}^{-1}$ was reached. Three straws, per ejaculate and per stallion, were thawed for each of the 2 extenders. The diluted spermatozoa were incubated at $37{ }^{\circ} \mathrm{C}$ for $10 \mathrm{~min}$ and motility parameters evaluated using computer-assisted analyses (IVOS, version 10, Hamilton Thorne, Beverly, MA, USA). The parameters analyzed were average path velocity (VAP, $\mu \mathrm{m} \cdot \mathrm{s}^{-1}$ ), percent progressive sperm cells (PROG: average path velocity higher than $30 \mu \mathrm{m} \cdot \mathrm{s}^{-1}$ and straightness of track higher than $80 \%$ ) and percent rapid sperm cells (RAP: average path velocity higher than $\left.30 \mu \mathrm{m} \cdot \mathrm{s}^{-1}\right)$. Analyses were performed in duplicate $(2 \times 3 \mu \mathrm{L}$ sampling/straw) with three fields analyzed (i.e. 6 observations/straw and 18 observations/stallion/ejaculate).

\subsection{Assessment of membrane integrity}

The membrane integrity of sperm cells was assessed by their response to a range of hypotonic steps [6]. Frozen semen was thawed ( 2 straws/ejaculate and 5 ejaculates/stallion) and diluted in INRA82 or INRA96 ${ }^{\circledR}$ until a concentration of $20 \times 10^{6}$ sperm cells. $\mathrm{mL}^{-1}$ was reached (the 2 straws were pooled). The diluted sperm cells were immediately centrifuged (500× $g$ for $4 \mathrm{~min}$ ) then re-suspended in a range of hypotonic Hank's salt solutions (supplemented with $4.76 \mathrm{~g} \cdot \mathrm{L}^{-1}$
Hepes buffer: 303, 205, 154, 103, 63, 35,12 mOsm identified as P0 to P6, respectively), and incubated for $15 \mathrm{~min}$ at $37^{\circ} \mathrm{C}$. Then the spermatozoa were diluted to $1 \times 10^{6} \cdot \mathrm{mL}^{-1}$, stained with $5 \mu \mathrm{L} \cdot \mathrm{mL}^{-1}$ propidium iodide (Invitrogen ${ }^{\mathrm{TM}}$, Molecular Probes ${ }^{\mathrm{TM}}$, Eugene, OR, USA; PI, final concentration $2.5 \mu \mathrm{g} \cdot \mathrm{mL}^{-1}$ ), and incubated for $5 \mathrm{~min}$ more at $37^{\circ} \mathrm{C}$ prior to flow cytometric analysis (MoFlo ${ }^{\circledR}$ Cell Sorter, Dako, Denmark). The response of sperm cells to the hypotonic steps was measured by propidium iodide (PI+\%). PI+ spermatozoa, incorporating the fluorescent probe, were considered as membrane-damaged.

\subsection{Mare management and insemination}

The genital tract of each mare was scanned by transrectal ultrasonography daily from the onset of estrus until ovulation. When a dominant follicle reached a diameter of $35 \mathrm{~mm}$, ovulation was induced by an intravenous injection of $15 \mathrm{mg}$ crude equine pituitary gonadotropin (day D0) [8] and insemination was performed on the following day (D1). Mares were randomly assigned to one of the two extenders. Mares were inseminated with one dose containing $400 \times 10^{6}$ total spermatozoa extended in $4 \mathrm{~mL}$ extender $(8$ straws were thawed and pooled) and placed in the uterine body. Our criteria for each ejaculate required $35 \%$ of rapid spermatozoa after thawing. Nevertheless, the motility of spermatozoa was reassessed before each insemination by microscopic analysis. All inseminations (done in August and September) were performed by the same person. If ovulation had not occurred on day 2, the cycle was eliminated from the protocol. If ovulation was double, the cycle was eliminated too. Inseminations were performed in a total of 84 mare cycles: 42 cycles with semen frozen in INRA82 extender supplemented with $2 \%$ egg yolk 
and $2.5 \%$ glycerol and 42 cycles with semen frozen in INRA96 ${ }^{\circledR}$ extender supplemented with $2 \%$ egg yolk and $2.5 \%$ glycerol. Pregnancy diagnosis was conducted on day 14 after ovulation by ultrasonography. Per-cycle pregnancy rate was calculated as the number of cycles resulting in pregnancy compared with the total number of cycles in which insemination was performed.

\subsection{Statistical analyses}

Comparisons of motility, membrane integrity and fertility were conducted with SAS software (SAS, Institute, Inc., Cary, NC, USA). Differences between means of motility parameters (VAP, PROG and RAP) were submitted to an analysis of variance using the GLM procedure of SAS. Percent sperm cells with membrane damage after exposure to the hypotonic steps (presented as percent PI+ sperm cells) were submitted to a factorial design with repeated measurements using the MIXED procedure of SAS. To take into account the repeated measurements we tested different covariance structures, in accordance with Littell et al. [11]. Differences between extenders at each osmotic pressure were also tested. The fertility results were analyzed by a generalized linear model using the GENMOD procedure of SAS. In each of these three procedures, effects of extender, of stallion, of ejaculate (effect of ejaculate and effect of date of collection are merged), as well as the different interactions between these factors were considered. Differences with values of $p<0.05$ were considered as being statistically significant.

\section{RESULTS}

\subsection{Motility parameters}

Comparisons of motility are reported in Figure 1. The average path velocity and percent progressive sperm cells were significantly higher for semen frozen in INRA82 compared with semen frozen in INRA96 ${ }^{\circledR}$ (VAP: $82 \mu \mathrm{m} \cdot \mathrm{s}^{-1}$ versus $66 \mu \mathrm{m} \cdot \mathrm{s}^{-1}$ and PROG: $51 \%$ versus $45 \%$, $p<0.0001)$. Percent rapid sperm cells was also significantly higher with INRA82 compared with INRA96 ${ }^{\circledR}(61 \%$ versus $58 \%, p<0.01)$. A significant stallion effect was observed for these three motility parameters. A significant ejaculate effect was also observed, except for RAP. Stallions or ejaculates appeared more easily discriminated (with the SNK grouping test) in INRA96 ${ }^{\circledR}$ than in INRA82. This observation was made for the three motility parameters.

\subsection{Membrane integrity}

The response profiles of spermatozoa after exposure to hypotonic steps, performed to assess membrane integrity, are presented in Figure 2. Response profiles of spermatozoa, as a whole, were different between the extenders. Indeed, percent PI+ spermatozoa (as an indicator of the percentage of sperm cells with membrane damage) was significantly lower for semen frozen in INRA $96^{\circledR}$ than in INRA82 extender $(p<0.05)$. Significant stallion $(p<$ $0.0001)$ and ejaculate effects $(p<0.001)$ were observed. The interaction "extender $\times$ osmotic pressure" was significant. For each osmotic pressure, differences between extenders were calculated. From P5 to P1, differences between extenders were significantly different from 0 (P5: $p<0.01$; P4: $p<0.001$; P3: $p<0.05$; P2: $p<0.05$; P1: $p<0.001)$. In contrast, for P6 and P0 these differences were not significantly different from $0(p>0.05)$.

\subsection{Per-cycle pregnancy rates}

Comparisons of fertility are reported in Figure 3 . The per-cycle pregnancy rate 


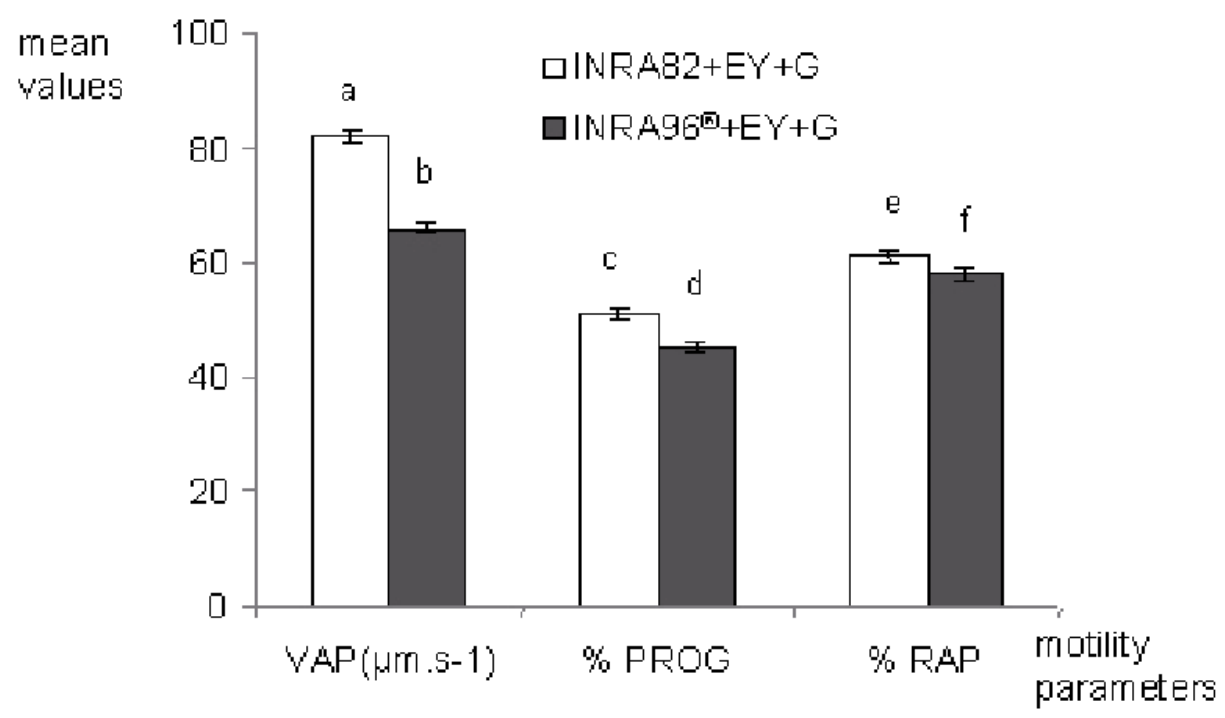

Figure 1. Comparison of motility parameters evaluated by CASA, after freezing in INRA82 and INRA96 ${ }^{\circledR}$ extenders, both supplemented with egg yolk (2\%) and glycerol $(2.5 \%)$. Mean values of VAP (average path velocity, $\mu \mathrm{m} \cdot \mathrm{s}^{-1}$ ), of PROG (percent progressive sperm cells: average path velocity higher than $30 \mu \mathrm{m} \cdot \mathrm{s}^{-1}$ and straightness of track higher than $80 \%$ ) and of RAP (percent rapid sperm cells: average path velocity higher than $30 \mu \mathrm{m} \cdot \mathrm{s}^{-1}$ ) are displayed $+/-$ standard error of the mean (SEM). For each of the 3 motility parameters, means with different letters are significantly different between extenders (a, b: $p<0.0001$; c, d: $p<0.0001$; e, f: $p<0.01$ ).

was significantly improved when semen was frozen in INRA96 ${ }^{\circledR}$ compared with INRA82 extender $(71 \%$ versus $40 \%, p<$ $0.01)$. The effect of ejaculate was significant $(p<0.05)$, whereas stallion was not. Fertility was indeed improved for each of the 3 stallions when semen was frozen in INRA96 ${ }^{\circledR}$ supplemented with egg yolk and glycerol.

\section{DISCUSSION}

Our results demonstrated that INRA96 ${ }^{\circledR}$ improved per-cycle pregnancy rates compared with the control extender. In agreement with these fertility results, plasma membrane integrity was better preserved in INRA96 ${ }^{\circledR}$ than in INRA82. In contrast, motility was higher in INRA82 than in INRA96 ${ }^{\circledR}$ extender.
In our study, motility parameters did not provide efficient estimates of fertility potential, which is often reported in the literature and underlined in the review of Petrunkina et al. [14]. We do not have any explanation for the discrepancy observed between motility parameters and fertility rates. In comparison with motility, the ability of sperm cells to adapt to changing osmotic conditions appeared to be a better indicator of their fertility potential. Indeed, the hypoosmotic swelling test (HOS test) has been widely used for this purpose in human and domestic species $[4,7,9,15,17]$. Most of the results indicate that the HOS test is a reliable and informative indicator of the functional integrity of the sperm plasma membrane. More recently, Leboeuf et al. [10] demonstrated that exposure of goat spermatozoa to a range of hypotonic steps can 


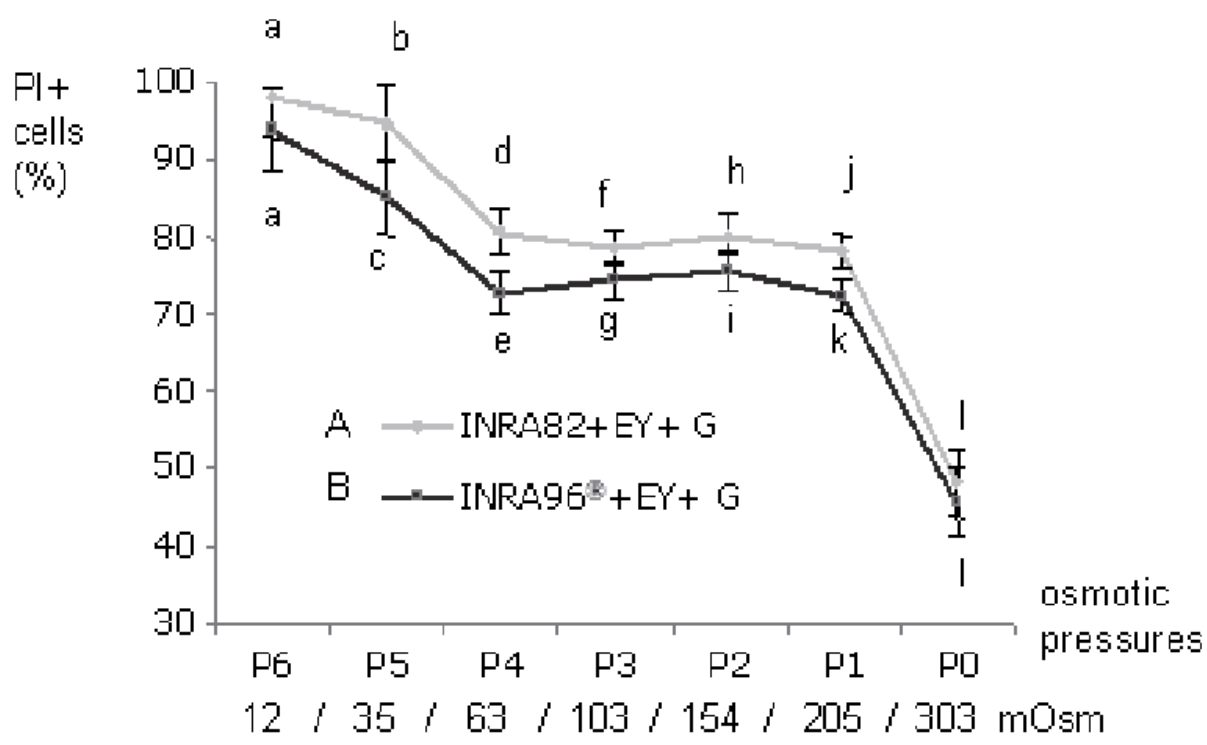

Figure 2. Comparison of the response profiles of spermatozoa exposed to a range of hypotonic steps after freezing in INRA82 and INRA96 ${ }^{\circledR}$ extenders, both supplemented with egg yolk $(2 \%)$ and glycerol $(2.5 \%)$. The response of sperm cells (as an indicator of membrane integrity) was measured by propidium iodide uptake (\% PI+), using flow cytometry. The response profiles are significantly different (A, B: $p<0.05$ ). For each osmotic pressure, means and the $95 \%$ confidence interval are displayed. Means with different letters are significantly different between extenders (a: NS $p>0.05$; b, c: $p<0.01$; d, e: $p<0.001$; f, g: $p<0.05$; h, i: $p<0.05$; j, k: $p<0.001$; 1: NS $p>0.05$ ).

provide evidence of differences between sperm storage methods, and between males or ejaculates. Our results, demonstrating improvement of sperm plasma membrane functionality after freezing in INRA $96^{\circledR}$ extender compared with INRA82, suggest that the composition of INRA96 ${ }^{\circledR}$ improves the protection of spermatozoa during the freezing and thawing processes. The high concentrations of sugars in INRA96 ${ }^{\circledR}$ could modify the freezing point of the extender and allow higher dehydration of the sperm cells, therefore reducing the formation of ice crystals [3].

The concentration of micellar caseins in INRA96 $^{\circledR}$ (native phosphocaseinate) is twice that in INRA82. Moreover, they are present in their native form, whereas INRA82 contains liquid ultraheat-treated (UHT) skim milk. The na- tive form of caseins is therefore modified. Caseins exist in milk as heterogeneous colloidal particles known as casein micelles. Basically, casein micelles are composed of a hydrophobic core of $\alpha$ - and $\beta$-caseins surrounded by $\kappa$-caseins. Hypothetically, this structural aspect of casein micelles associated with sugars may create a physical protection for sperm cell membranes during cryopreservation. Further research is required to understand how INRA96 ${ }^{\circledR}$ components protect spermatozoa during the cryopreservation process and increase their fertility potential compared with INRA82.

In conclusion, INRA96 ${ }^{\circledR}$ supplemented with egg yolk and glycerol was an efficient extender for freezing stallion semen and improved per-cycle pregnancy rates compared with the control extender. 


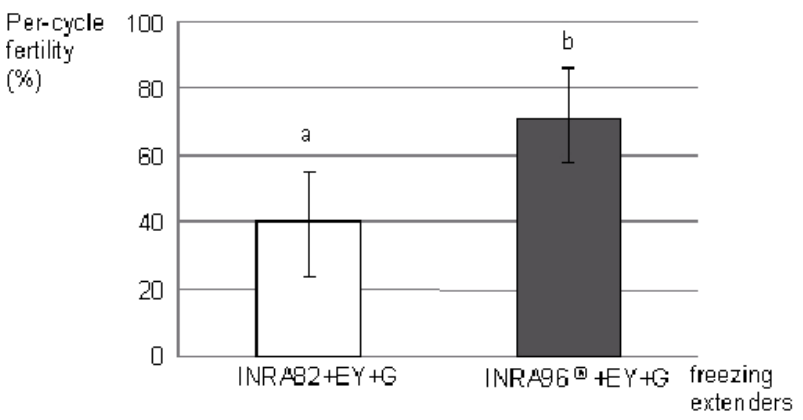

Figure 3. Per-cycle pregnancy rates after artificial insemination with semen frozen in INRA82 or INRA96 ${ }^{\circledR}$ extenders, both supplemented with egg yolk (2\%) and glycerol (2.5\%). 17 pregnancies/ 42 inseminations $(40 \%)$ versus 30 pregnancies/42 inseminations $(71 \%)$. Fertility results and the $95 \%$ confidence interval are displayed. Fertility results with different letters are significantly different (a, b: $p<0.01)$.

This fertility trial needs further replication in a different location in order to confirm the high pregnancy rates obtained with semen frozen in INRA96 ${ }^{\circledR}$ extender.

Acknowledgements: Elodie Pillet is a Ph.D. student financially supported by IMVTechnologies and ANRT. Dr. J.-L. Maubois and Dr. J.P. Brillard (INRA) are acknowledged for their expert advice, and Mr. B. Bruneau and Mr. J.M. Yvon for their help during the fertility trial.

\section{REFERENCES}

[1] Barker C.A.V., Gandier J.C.C., Pregnancy in a mare resulting from frozen epididymal spermatozoa, Canadian Journal of Comparative Medical Veterinary Science 21 (1957) 47-41.

[2] Batellier F., Magistrini M., Fauquant J., Palmer E., Effect of milk fractions on survival of equine spermatozoa, Theriogenology 48 (1997) 391-410.

[3] Bryant G., Koster K.L., Steponkus P.L., Wolfe J., Effects of sugars on the stability of biological and model membranes at low hydratations: a consequence of specific sugarlipid interactions or simple physical effects of the solute? 38th Meeting of the Society for Cryobiology, Edinburg, 2001.

[4] Caiza de la Cueva F.I., Rigau T., Bonet S., Miro J., Briz M., Rodriguez-Gil J.E.,
Subjecting horse spermatozoa to hypoosmotic incubation: effect of ouabaïn, Theriogenology 47 (1997) 765-784.

[5] Chanavat E., Vidament M., Defoin L., Duchamp G., Levillain N., Yvon J.M., Le Vern Y., Kerboeuf D., Magistrini M., Effects of storage and temperature on in vitro stallion sperm parameters and fertility rate, Anim. Reprod. Sci. 89 (2005) 318-321.

[6] Defoin L., David C., Le Vern Y., Kerboeuf D., Magistrini M., Hypoosmotic swelling test: a new approach by multi-hypotonic steps, Anim. Reprod. Sci. 89 (2005) 219223.

[7] Drevius L.O., Ericksson H., Osmotic swelling of mammalian spermatozoa, Exp. Cell Res. 42 (1996) 136-156.

[8] Duchamp G., Bour B., Combarnous Y., Palmer E., Alternatives solutions to hCG induction of ovulation in the mare, J. Reprod. Fert. 35 (1987) 221-228.

[9] Jeyendran R.S., Van der Ven H.H., PerezPelaez M., Grabo B.G., Zaneveld L.J.D., Development of an assay to assess the functional integrity of the human sperm membrane and its relationship to other semen characteristics, J. Reprod. Fertil. 70 (1984) 219-225.

[10] Leboeuf B., Le Vern Y., Furstoss V., Kerboeuf D., Guillouet P., Magistrini M., Response of goat sperm to hypoosmotic steps modelled probit analysis, Anim. Reprod. Sci. 91 (2006) 265-274.

[11] Littell R.C., Henry P.R., Ammerman C.B., Statistical analysis of repeated measures data 
using SAS procedures, J. Anim. Sci. 76 (1998) 1216-1231.

[12] Magistrini M., Couty I., Palmer E., Factors influencing stallion sperm survival, Acta Vet. Scand. Suppl. 88 (1992) 97-110.

[13] Palmer E., Factors affecting stallion semen survival and fertility, Proc. 10th Int. Congr. Anim. Reprod. and A.I., Urbana (1984) 377379.

[14] Petrunkina A.M., Waberski D., Günzel-Apel A.R., Töpfer-Petersen E., Determinants of sperm quality and fertility in domestics species, Reproduction 134 (2007) 3-17.

[15] Revell S.G., Mrode R.A., An osmotic resistance test for bovine semen, Anim. Reprod. Sci. 36 (1994) 77-86.
[16] Samper J.C., Morris C.A., Current methods for stallion semen cryopreservation: a survey, Theriogenology 49 (1998) 895-903.

[17] Vasquez J.M., Martinez E.A., Martinez P., Garcia-Artiga C., Roca J., Hypoosmotic swelling of boar spermatozoa compared to other methods for analysing the sperm membrane, Theriogenology 47 (1997) 913-922.

[18] Vidament M., French field results (19852005) on factors affecting fertility of frozen stallion semen, Anim. Reprod. Sci. 89 (2005) 115-136.

[19] Watson P.F., The causes of reduced fertility with cryopreserved semen, Anim. Reprod. Sci. 60-61 (2000) 481-492. 